University of Nebraska - Lincoln

DigitalCommons@University of Nebraska - Lincoln

Publications, Agencies and Staff of the U.S. Department of Commerce

U.S. Department of Commerce

$11-1988$

Sperm competition in grey whales

Katherine Ralls

National Zoological Park, Srnithsonian Institution, Washington, DC

Robert L. Brownell Jr.

US Fish and Wildlife Service, rlbcetacea@aol.com

Follow this and additional works at: https://digitalcommons.unl.edu/usdeptcommercepub

Part of the Environmental Sciences Commons

Ralls, Katherine and Brownell, Robert L. Jr., "Sperm competition in grey whales" (1988). Publications, Agencies and Staff of the U.S. Department of Commerce. 123.

https://digitalcommons.unl.edu/usdeptcommercepub/123

This Article is brought to you for free and open access by the U.S. Department of Commerce at DigitalCommons@University of Nebraska - Lincoln. It has been accepted for inclusion in Publications, Agencies and Staff of the U.S. Department of Commerce by an authorized administrator of DigitalCommons@University of Nebraska - Lincoln. 
This article is a U.S. government work, and is not subject to copyright in the United States.

\section{Sperm competition in grey whales}

SIR-Your' legend for the drawing of grey whales taken from Cyall Watson's book Whales of the World, perpetuates the myth that a 'helper' male is necessary for successful mating in this species. The legend states that: "Only one male is involved in the actual mating; the other takes an upright position on the far side of the female, acting as a prop or wedge". This description of grey whale mating behaviour, paraphrased from Watson's book, can be traced to Samaras 2 .

All accounts of mating behaviour in grey whales note that more than one male is involved. Although Samaras believed that the most common group consisted of two males and a female, mating groups of up to 18 animals have been observed ${ }^{3}$. Mating groups may last for up to two hours but change composition as individual males leave or join ${ }^{4}$. These groups probably consist of a single oestrous female and numerous males. Swartz's detailed observations have shown that mating within these groups is not confined to a single male: the female "repeatedly copulates with more than one male during the same mating bout". Samaras interpreted the trios of two males and a female sometimes seen in grey whales as a mating couple and an additional 'helper whale' but it is now believed that this is a misinterpretation and that multiple males are copulating with the female and competing through sperm competition in mating groups of all sizes. ${ }^{3.5}$. We have pointed out that the relatively large testes, long penises, copulations of one female with several or many males, and the relatively unaggressive male-male interactions in right, bowhead and grey whales are characteristic of polygynous species where males compete by sperm competition rather than by aggressive interactions 5 .

I. Nature 335. 125 (1988)

2. Samaras, W.F. Bull. Southern Calif. Acad. Sci. 73. 57-64 (1974).

3. Swartz. S.L. Rep. Int. Whal. Commn spec. Issue 8, 207-229 (1986). 
These features are found in species throughout the animal kingdom, ranging from insects to primates, where males compete primarily by sperm competition ${ }^{5.6}$.

National Zoological Park,

Katherine Ralls

Smithsonian Institution,

Washington, DC 20008, USA

ROBERT L. BROWNELL, JR US Fish and Wildlife Service,

PO Box 70,

San Simeon, California 93452, USA 